\title{
Governance for sustainable tourism: A review and directions for future research
}

\author{
Maria do Rosário Borges ${ }^{1 *}$, Celeste Eusébio ${ }^{2}$ and Nuno Carvalho ${ }^{3}$
}

Received: 01/03/2013 Accepted: 02/08/2013

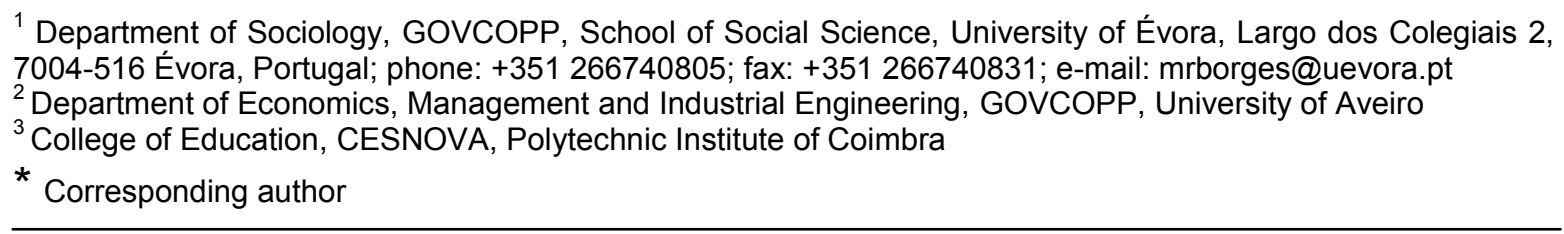

\section{Abstract}

Over the past two decades there has been a growing interest in the topic of governance in the context of several domains of the social sciences. More recently, the growing attention given by investigators to governance and its implication for tourism development has raised several core questions. However, research is still fragmented and different interpretations of the governance concept might lead to multiple reflections. This paper aims to present and discuss some fundamental theoretical issues related to governance within the context of tourism, tourism destinations and sustainable development. Conceptualisation, dimension and scale of governance are presented based on a literature review. This approach will also be used to do a synthesis of the main methodologies that have been used so far for data collection and analysis in scientific studies within these fields. The paper argues that the concept of governance is multidimensional and that there are no standardized solutions to ensure success through a universal approach to governance. Private and public sector and other actors are being forced to promote synergies within the same geographical area of intervention in order to face global competition and governance arrangements can facilitate this. The review also reveals that there is still only limited systematic and comparable empirical evidence of the role of governance in sustainable tourism destinations. Finally, because governance might represent a new pattern of interaction between government, private sector and society to cope with old and new problems or to create new opportunities to develop a sustainable tourism, some pathways for future research on this topic are also identified.

(C) 2014 International University College. All rights reserved

Keywords: governance, sustainable tourism, tourism destination, literature review, Scopus

Citation: Borges, M., C. Eusébio and N. Carvalho (2014) Governance for sustainable tourism: A review and directions for future research. European Journal of Tourism Research 7, pp. 45-56

\section{Introduction}

Tourism, governance and sustainable development embody three multifaceted and composite domains of knowledge that raise numerous important questions and concerns when combined. In the tourism literature more 
established terms and activities related to tourism politics, policy, policy-making and planning, and destination management (Bramwell and Lane, 2011) have thus far allowed investigators to have a relatively coherent set of scientific knowledge. Because sometimes these terms overlap with governance (e.g. political agenda and debate) this enables them to contribute to continued progress in several sub-fields, in which social science literature on governance can make an important contribution. But still further efforts should be made in order to improve the quality and diversity of scientific studies, based on appropriate theoretical approaches and on empirical studies. Despite some cases of success around the world, there is a general consensus among researchers that sustainable development of tourism is complex and problematic and it is still far from achieving the desired key-principles and aims into practice (Hunter, 1997; Ko, 2005; Liu, 2003; McDonald, 2009). The journey towards achieving sustainability goals stills goes on. Tourism is a global phenomenon that is shaped locally; in these two limits, and between them, much work remains to be done. New forms of relationships between state, economic interests and civil society are imperative to face global challenges and governance seems to have the capacity to referee this approach. According to Bramwell (2011:461) "destinations wanting to promote sustainable tourism are more likely to be successful when there is effective governance".

Proper framework of governance seems to be in the forefront of the initiatives to overcome the global problems and challenges posed by sustainable development. Very recently, the 2012 UN Conference on Sustainable Development underlined that human societies still continue to bring about irreversible impacts on the earth system and clearly advocate that reform of current governance for global sustainability is urgent. Also the Organisation for Economic Co-operation and Development (OECD) advocates that "good governance practices can help to facilitate an integrated, whole-of-government approach to tourism (...); effective governance practices must reflect the changing business and policy environment" (OECD, 2012:9).
A research to perceive how far governance approach has been applied to the development of sustainable tourism would be of great importance. Fundamental theoretical issues related to governance philosophy present a very broad scope for analysis. Approaching governance literature calls for a wider overview of the various governance concepts, the different disciplinary approaches to governance, the scope of governance theory, and the challenges associated with specific practical areas of governance. Otherwise, it would be more difficult to understand why several authors (e.g. Grindle, 2007; Hall, 2005 and 2008; Jessop, 1998; Paavola, Gouldson and Kluvánková-Oravská, 2009; Rhodes, 1996; Stoker, 1998; Sumner, 2008; Windsor, 2009) argue that governance issues are thorny, complex, diversified, diffuse and sometimes contradictory.

This study aims to present and discuss some core theoretical issues related to governance and sustainable tourism, such as concepts, dimensions, scale and methodological discourse, which are expressed in some articles published in this specific field. Taking as a reference the work already done by Lu and Nepal (2009), about sustainable tourism research, the perspective of how governance has been approached to improve the development of sustainable tourism was prioritised in this research. To meet the objectives, a literature review was made.

\section{Methodology}

This paper examines conceptual and empirical articles about governance in the context of sustainable tourism. In order to identify the units of analysis - scientific articles - research was carried out in the Scopus database. Preference was given to this database because it "is the world's largest abstract and citation database of peer-reviewed literature, with smart tools to track, analyse and visualize research" (Elsevier, 2012). The data collection was made in the month of May 2012 and reviewed in September 2012. The survey was carried out in two different stages.

\section{First step - data collection and results}

As a first step, a quantitative analysis of scientific articles published since 1960 was 
Table 1. Research orientations used to identify articles

\begin{tabular}{ccccc}
\hline $\begin{array}{c}\text { Type of } \\
\text { analysis }\end{array}$ & $\begin{array}{c}\text { Period of data } \\
\text { collection }\end{array}$ & $\begin{array}{c}\text { Information } \\
\text { fields }\end{array}$ & \multicolumn{1}{c}{ Searched keywords } & $\begin{array}{c}\text { Number of } \\
\text { academic } \\
\text { articles }\end{array}$ \\
\hline & & & $\begin{array}{l}\text { Tourism and governance } \\
\text { Tourism, governance and sustainable }\end{array}$ & $\begin{array}{c}221 \\
51\end{array}$ \\
Quantitative & \multirow{2}{*}{$\begin{array}{l}\text { Tourism, governance and } \\
\text { Analysis }\end{array}$} & & $\begin{array}{l}\text { Title, Abstract } \\
\text { and Key-words }\end{array}$ & $\begin{array}{l}\text { Sustainability } \\
\text { Tourism, governance, sustainable and } \\
\text { sustainability }\end{array}$ \\
\hline
\end{tabular}

Table 2. Evolution of the number of articles found in Scopus, 1976-2012

\begin{tabular}{|c|c|c|c|c|c|}
\hline \multirow[b]{2}{*}{ Year } & \multicolumn{4}{|c|}{ Search codes } & \multirow{2}{*}{$\begin{array}{l}\text { Articles } \\
\text { considered } \\
\text { relevant for } \\
\text { the analysis }\end{array}$} \\
\hline & $\begin{array}{l}\text { Tourism and } \\
\text { governance }\end{array}$ & $\begin{array}{c}\text { Tourism, } \\
\text { governance and } \\
\text { sustainable }\end{array}$ & $\begin{array}{l}\text { Tourism, } \\
\text { governance and } \\
\text { sustainability }\end{array}$ & $\begin{array}{c}\text { Tourism, governance, } \\
\text { sustainable and } \\
\text { sustainability }\end{array}$ & \\
\hline 2012 & 20 & 3 & 2 & 5 & - \\
\hline 2011 & 56 & 14 & 7 & 16 & 6 \\
\hline 2010 & 22 & 6 & 3 & 7 & 4 \\
\hline 2009 & 32 & 9 & 5 & 10 & 2 \\
\hline 2008 & 16 & 4 & 3 & 6 & 1 \\
\hline 2007 & 16 & 3 & 1 & 4 & 1 \\
\hline 2006 & 18 & 5 & 4 & 5 & 1 \\
\hline 2005 & 9 & 1 & 1 & 1 & 1 \\
\hline 2004 & 6 & - & 2 & 2 & - \\
\hline 2003 & 3 & 1 & - & 1 & 1 \\
\hline 2002 & 3 & 2 & 1 & 2 & - \\
\hline 2001 & 6 & 1 & - & 1 & - \\
\hline 2000 & 4 & - & - & - & - \\
\hline 1999 & 3 & 2 & 1 & 2 & 2 \\
\hline 1998 & 2 & - & - & - & - \\
\hline 1996 & 1 & - & - & - & - \\
\hline 1994 & 1 & - & - & - & - \\
\hline 1993 & 1 & - & - & - & - \\
\hline 1990 & 1 & - & - & - & - \\
\hline 1976 & 1 & - & - & - & - \\
\hline Total & 221 & 51 & 30 & 62 & 19 \\
\hline
\end{tabular}

conducted; book reviews, reports or comments were not included in the analysis. The period covered was the widest permitted by the Scopus platform (1960 to 2012). The research was conducted in the Social Sciences \& Humanities subject area. The code scheme used aimed to identify articles that bring together the three words - 'tourism', 'governance' and 'sustainable' (or 'sustainability'), whether they were in the title, abstract or key-words.

Results obtained are briefly presented in Table 1. The number of articles published about tourism and governance $(n=221)$ presents a significant awareness of these general combined research domains. The results separated for 'tourism, governance and sustainable' search code $(n=51)$ or 'tourism, governance and sustainability' $(n=30)$ displayed different results, although some were found to be coincident. A total of 62 scientific articles published in journals were identified by Scopus database for the initial purpose of the present analysis, across three areas of knowledge.

All of the 62 articles were reviewed and filtration was made via abstract reading by the authors. Only 19 of them were considered as directly relevant to the combined subject matters of this reflection. The list is provided in Appendix A. One of the main reasons to reject 
43 articles is due to the fact that, although some of them presented the words 'governance', 'tourism', 'sustainable' and 'sustainability' in the information fields, they were referred to in a superficial or circumstantial way to the investigation per se; it seems that it was only a matter of standard rhetoric. In other cases the term tourism appeared in the context of a wide range of other activities, but not subject to individualized analysis. Also, sometimes the word governance didn't appear in the title, abstract or authors key-words, but only in the GeoBase subject index of the Scopus database.

Table 2 data represents the evolution of the number of articles found with the search terms, by year. The code scheme was used to carry out the research simultaneously in the titles, abstracts and key-words of the articles published after 1960. The last column of Table 2 represents the 19 articles that were considered directly relevant to the combined analysis of subject matters of this reflection and thus allow the presentation and discussion of some theoretical issues related to governance within the context of the sustainable development of tourism.

Until 1975 the survey did not reveal any published articles. The first article relating tourism and governance was published in 1976 in the Annals of Tourism Research, with the title The Tourism Policy. In the 80s Scopus did not identify any publications and the second article found was published in 1990, in the Cities review, with the title Honolulu. During the 90 s the number of publications began to increase at a very modest rate, although this decade was marked by the official start of the international community engagement with initiatives to promote the development of sustainable tourism. In the early 2000 s several international and national players were already advocating a focus on new structures and governance procedures to overcome the failure of sustainability policies, but only from the year 2006 did the rate of publications begin to grow more significantly than in previous years. But even so, the frequency of publications does not present regular behaviour, with alternating growth and decrease in the number of publications. The year 2011 recorded the greatest number of publications in the period under review.

Specifically, considering only the last column of Table 2, which shows the evolution of the number of publications for the relevant 19 articles, data evidences that governance and sustainable tourism has grown very slowly as an area of academic interest. The first two papers were Governance in Context: Boracay Island, Philippines and Rethinking Collaboration and Partnership: A public policy perspective respectively published in the Annals of Tourism Research and in the Journal of Sustainable Tourism, in 1999. Only in the present decade did researchers demonstrate increased interest in researching these three areas combined. In 2011 all 6 articles were published in the same journal - the Journal of Sustainable Tourism which published a special issue on Tourism governance: Critical perspectives on governance and sustainability (Volume 9, Issues 4-5). The editors of the journal explained the importance of the special issue arguing that until then governance had not been researched and discussed at a pace as dynamic as other issues related to it in tourism (Bramwell and Lane, 2011). Despite this special issue containing a total of 13 articles related to governance and sustainable tourism, Scopus data only identified 6 .

\section{Second step - content analysis}

As a second step of research, a qualitative synthesis was supported by reading the full content of the 19 scientific articles. Data were divided according to the following parts of analysis: concepts; dimensions; scale of governance; and methodology, in relation to the aims defined. For each part, very brief considerations are also made in the next section based on a general literature review to better explain some findings.

\section{Results and discussion}

The growing interest in governance issues in several scientific and professional domains raised a complex body of knowledge to deal with, especially for researchers who do not have a political background.

\section{Concept of governance}

One of the first references to governance in the literature, particularly usage of the corporate 
governance concept, goes back to the seventeenth century (Ruhanen, Scott, Ritchie and Tkaczynski, 2010) but since then several concepts (e.g. environmental governance, European governance, good governance, multi-level governance, urban governance) have emerged independently and are used in different dialogue contexts, by different societal actors and with a special focus. After the Second World War, socio-political dynamics revitalized the concept and practice of governance and, in addition, researchers in several areas of social sciences (e.g. public administration and public policy, comparative politics, economics, international relations, development studies) analysed and tracked its revival and progress. Governance is different from the term govern: it includes interaction between multiple actors (public and private sector, and civil-society actors), and can be used "in a variety of ways and has a variety of meanings" (Stoker, 1998:17), which is even more evident today. In the context of the social sciences the debate on governance can be exploited using either broad or narrow definitions (Bevir, 2007). In a broad sense, governance addresses general issues about social coordination and inter-organizational links, very focused on the types of governance structures (e.g. hierarchy, market, networks, and communities). In a narrow approach, governance can be approached from the perspective of the proliferation and action of networks in which the state and other actors depend on each other. Several authors have analysed and commented on the proliferation of concepts. For instance, Weiss (2000) presented a critical analysis about governance, good governance and global governance concepts. Also Grindle (2007) systematized some of the most quoted governance and good governance concepts used by both international organisations and researchers. Kjær (2004:4) drew attention to the fact that different concepts "are used in different subfields of political science, and therefore they refer to different debates".

In tourism research contexts, a governance approach also reflects its diversity and complexity. Beaumont and Dredge (2010:8) stated that "governance is an increasingly popular term used to denote 'all forms of organisational relationships' (Edwards, 2002)", but this reference by itself is not enough to set a more focused field of investigation. Because governance can be defined in several different ways, concepts about governance were identified from the sample of papers being studied, although not all articles present definitions and reflections on its meanings and possible application to tourism. Hall (1999:275) presented one of the most cited definitions of governance in the literature: "governance through network structures as a 'new process of governing; or a changed condition of ordered rule; or the new method by which society is governed' (Rhodes, 1997:43)". Trousdale (1999:842) distinguished a concept which also refers to several possible dimensions of governance: "Governance is defined as the ability to coordinate the aggregation of diverging interests to promote policy, projects, and programs that credibly represent the public interests. Public involvement, institutional development, transparency of decision making procedures, interest representation, conflict resolution, limits of authority, and leadership accountability are all issues of governance (Frischtak 1994)". Some important national and international organizations also have their own understanding about governance which were cited several times by researchers, as is the case of the United Nations, OECD or the International Monetary Fund. As concerns all the papers on this analysis, only Shipley \& Kovacs (2008:215) presented a definition of this type. They presented the concept of the Canadian Institute on Governance as cited: "governance is a dynamic interaction involving 'structures, functions (responsibilities), processes (practices) and organizational traditions that the board of an organization uses to accomplish the organizing mission' " (Shipley and Kovacs, 2008:215). Alongside the concept of governance, some derivations on the same concept were also recognized as good governance (Beaumont and Dredge, 2010; Plummer and Fennell, 2009; Shipley and Kovacs, 2008), collaborative governance (Jamal and Watt, 2011) and governance in the context of regional and local level (Zahra, 2011). The common underlying feature of governance concepts is that they imply concerted interactions between several actors towards social purposes, which aim to be more 
effective than the state was before in doing the work on its own, lone and authoritative, in past decades. In the context of the present article this focus is due to the fact that in the group of articles analysed, the majority of the approaches do not present theoretical or empirical reflections related to corporate governance.

\section{Dimensions of governance}

Moving from the conceptual level to more operational levels, numerous dimensions of governance can be employed to better grasp this broad concept, and examine how well actors are involved in achieving aims (Bevir, 2007). In the literature a plurality of dimensions of governance can be found, also assigned by variables, characteristics, key elements or features. In this respect, Ruhanen et al. (2010) presented a comprehensive list with 40 dimensions of governance, based on an analysis of 53 articles. The results highlighted that for both fields of analysis (political science and corporate management) the 7 most commonly cited dimensions were: (i) accountability; (ii) transparency; (iii) involvement; (iv) structure; (v) effectiveness; (vi) power; and (vii) efficiency. They pointed out that "almost half of all dimensions examined in the governance literature pertain to the context of the particular study being undertaken by the author/s" (Ruhanen et al., 2010:11). Based on the articles analysed in this paper, it is possible to reach similar findings. Moreover, this shows that there still isn't a theoretical framework in this area. Several dimensions are mentioned according to the type of governance concept used, types of tourism, scale and underlying theories. For instance, Beaumont and Dredge (2010) did an extensive review of the literature to identify dimensions of governance in order to establish the parameters to examine local tourism governance networks. They listed 6 dimensions: (i) positive cultures, constructive communication and engaged communities; (ii) transparency and accountability; (iii) vision and leadership; (iv) acceptance of diversity and the pursuit of equity and inclusiveness; ( $v$ ) developing knowledge, learning and sharing expertise; and (vi) clear roles and responsibilities of participants and clear operational structures and processes of the network. The approach of governance to cultural heritage institutions developed by Shipley and Kovacs (2008) was done using 5 'principles of good governance' and related 'criteria'. The 5 principles, which they also designated as good governance attributes, were: (i) legitimacy and voice; (ii) direction; (iii) performance; (iv) accountability; and ( $v$ ) fairness. In the remaining articles, systematized lists of dimensions were not found, although some of them are referred to in the reflections presented throughout the articles. Moreover, the use of synonyms can add some divergence or difficulty in the definition of variables for analysis. Currently, this diversity of dimensions still translates into great difficulty in outlining models of analysis that can be replicated and evaluated in comparative terms, in various contexts of tourism, and even more in the specific context of sustainable tourism. In these particular cases, identifying theoretical constructs for future research becomes a harder task.

\section{Scale of governance}

Scale "is a critical element in environmental and social science research" (Hall, 2008:81). According to the author, sustainable subjects and related problems are visible themselves at various scales (spatial scales, temporal scales and scales of governance) and any type of analysis and/or intervention should take into account the different existing scales to accurately assess and deal with those subjects and problems with more success. From Bramwell and Lane's (2011) perspective, governance can also take place in different geographical scales. As far as spatial scale is concerned, analysis can be done related to site, local, regional, national and transnational (supranational and international) levels; the scales of governance are the same five units as mentioned, plus sectoral and personal (Hall, 2008).

Table 3 summarises the scale of governance applied to several researches in the articles under analysis. The spatial scale analysis is generally used to assess the dynamics of governance within an approach to the tourism system context. Identifying the scale of analysis sometimes raised certain classification doubts when the authors did not indicate expressly whether the study area is considered at a local 
Borges, M., C. Eusébio and N. Carvalho (2014) / European Journal of Tourism Research 7, pp. 45-56

Table 3. Scale of governance applied to studies

\begin{tabular}{lll}
\hline Author(s) & Scale focus: site or sector \\
\hline Hall (1999) & National & Australia, Canada, United States, United Kingdom, \\
Trousdale (1999) & Island & $\begin{array}{l}\text { Philippines - Boracay Island } \\
\text { Tunisia - Zouaraa }\end{array}$ \\
Caffyn and Jobbins (2003) & Local & Morocco - Restinga-Smir \\
Vernon, Essex, Pinder and Curry & Local & United Kingdom - Caradon District Council, Cornwall \\
(2005) & National & Netherlands \\
Dinica (2006) & Sectoral & Cultural Heritage Institutions \\
Shipley and Kovacs (2008) & National & Netherlands \\
Dinica (2009) & Local & $\begin{array}{l}\text { Australia - Redland City Council, Brisbane, State of } \\
\text { Queensland }\end{array}$ \\
Beaumont and Dredge (2010) & Turkey - Antalaya \\
Erkus-Öztürk and Eraydin (2010) & Regional & Australia - Ningaloo Reef \\
Moore and Rodger (2010) & Local & 2009 Australian World Rally Championship - Northern \\
Dredge and Whitford (2011) & Sectoral & Rivers Region \\
Higgins-Desbiolles (2011) & Local & Australia - Kangaroo Island \\
Jamal and Watt (2011) & Local & Canada - Mountain Resort of Canmore, Bow Valley, \\
Sofieldand Li (2011) & National & Alberta Region \\
Zahra (2011) & China \\
\hline
\end{tabular}

or regional level in the context of the country's administrative organisation being dealt with. A brief international outlook on the issues of tourism governance scale is possible as a reference. This range of articles under analysis includes, to no surprise, countries where some of the best known researchers in tourism do their work and, as far as developed countries are concerned, also study cases of best practices where usually significant events first happened.

Based on the papers reviewed in this research, Dredge and Whitford (2011) presented a sectoral approach to events in the automobile sector and Shipley and Kovacs (2008) to nongovernmental and public sector governance in the cultural heritage sector. Also temporal analyses are very important in governance to assess circumstances, results and trends. Furthermore, it is especially important in the context of sustainable tourism due to that fact that its objectives are related to long time horizons, although it is not easy to promote governance guided by objectives for sustainable tourism (Bramwell and Lane, 2011). But approaching governance with an evolving and adaptive approach has not been studied so far as has been the case with geographical scale. On the basis of prior and new experiences Hall (2011) advocates for 'policy learning'. Tourism governance is not static because of the changing political context and its environment, and also because previous outcomes give meaning to the next stage of policy-making and planning.

\section{Methodological discourse}

Both conceptual papers and empirical studies are presented and are important for the discussion undergoing. The first group of papers aims to identify and assess conceptual issues and theoretical frameworks in order to explore and describe the governance of sustainable development in tourism, without including primary data collection and analyses. According to Bramwell and Lane (2011:414), "theoretical frameworks are crucial to research on tourism governance because they influence what is studied, how it is studied, the conclusions reached, the recommendations proposed as well as the political implications of the research". Articles with theoretical analysis were presented by Lasing and Vries (2007) and 
Table 4. Type of data used

\begin{tabular}{ll}
\hline \multicolumn{1}{c}{ Type of data } & \multicolumn{1}{c}{ Sources } \\
\hline Primary data & Erkus-Öztürk and Eraydin (2010) \\
\hline Secondary data & Hall (1999); Trousdale (1999); Vernon, Essex, Pinder and Curry (2005); Dinica (2006); \\
& Moore and Rodger (2010); Sofield and Li (2011); Higgns-Desbiolles (2011); Jamal and \\
& Watt (2011); Hall (2011) \\
\hline Primary and & Caffyn and Jobbins (2003); Dinica (2009); Beaumont and Dredge (2010); Dredge and \\
secondary data & Whitford (2011); Zahra (2011); Higgns-Desbiolles (2011) \\
\hline
\end{tabular}

Table 5. Methodologies for collecting primary data within empirical studies

\begin{tabular}{lll}
\hline \multicolumn{1}{c}{ Author(s) } & \multicolumn{1}{c}{ Instrument(s) } & \multicolumn{1}{c}{ Target(s) } \\
\hline $\begin{array}{l}\text { Dinica (2009) } \\
\text { Beaumont and Dredge (2010) }\end{array}$ & $\begin{array}{l}\text { Survey } \\
\text { Semi-structured interviews }\end{array}$ & $\begin{array}{l}\text { 92 key Dutch tourism stakeholders } \\
5 \text { individuals involved in local tourism } \\
\text { management }\end{array}$ \\
Erkus-Öztürk and Eraydin (2010) & $\begin{array}{l}\text { Face-to-face in-depth interviews and } \\
\text { survey questionnaire }\end{array}$ & $\begin{array}{l}335 \text { applications of the questionnaire } \\
\text { to top tourism agents }\end{array}$ \\
$\begin{array}{l}\text { Dredge and Whitford (2011) } \\
\text { Zahra (2011) }\end{array}$ & $\begin{array}{l}\text { Semi-structured interviews } \\
\text { Observation of meetings, forums, } \\
\text { conferences and speeches and } \\
\text { presentations; interviews, focus groups } \\
\text { and an online questionnaire } \\
\text { Focused interviews (face-to-face, via }\end{array}$ & 125 tourism stakeholders \\
& telephone or via email) & \\
\hline
\end{tabular}

Plummer and Fennell (2009). The only editorial article identified was presented by Bramwell and Lane (2010). In Table 4 the type of data used by researches to conduct their reflections are identified.

Multiple data sources were often used to represent a scenario of governance over time (temporal scale) and across different spatial scales and sometimes to have a base to construct a theoretical framework for empirical analysis. Secondary data are often based on information provided by national or regional state agencies (e.g. government reports, regional plans, tourism strategies), council documents, international charters and conventions, parliamentary transcripts, legal documents and governmental policies, corporate plans, technical reports, socioeconomic and demographic data, archival resources, media sources (e.g. media releases and media reports). Public documents have a significant weight in governance-related analysis because state organizations, plans, actions and performance are, in almost all cases, at the centre of discussion.

The most popular ways to collect primary data consist of social survey methods. Data in Table 5 evidences that the target public under study is, almost always, a group composed of multiple stakeholders, reflecting the indications expressed in various concepts of governance and also in official documents, at international (e.g. Agenda 21 for Travel and Tourism) and national (e.g. Local Agenda 21) levels, guiding policies for the development of sustainable tourism. Quantitative analysis is the option of choice by most authors to describe the results of research reflections: Beaumont and Dredge (2010); Caffyn and Jobbins (2003); Dredge and Whitford (2011); Dinica (2006); Dinica (2009); Hall (1999); Higgns-Desbiolles (2011); Jamal and Watt (2011); Moore and Rodger (2010); Sofield and Li (2011); Trousdale (1999); Vernon, Essex, Pinder and Curry (2005) and Zahra (2011). Only Erkus-Öztürk and Eraydin (2010) reported results with a mixed-method approach, also referring specifically to the support software used. This evidences the fact that authors give importance to quantitative analyses of governance problematics in sets of social and political complexity, within the development of sustainable tourism. Regarding the theoretical analysis made, it is considered that the most appropriate would be the use of a mixed-methods approach due to the complexity of the phenomenon and also the diversity of stakeholders that should be involved when a 
tailored approach to governance is seen as a viable solution. The approach via study case study to illustrate subjects was often applied (e.g. Caffyn and Jobbins, 2003; Dredge and Whitford, 2011; Jamal and Watt, 2011; Moore and Rodger, 2010; Vernon, Essex, Pinder and Curry, 2005). No further reflections can be made in accordance with epistemological choices and other reality representations because these rarely appear referenced by the authors in these 19 articles under analysis.

\section{Conclusion and pathways for future research}

This study had the major purpose of conducting a focused literature review, in order to systematize the main reflections already made about governance and sustainable tourism in the scientific studies of social sciences. The review clearly reveals that there is still only limited systematic and comparable empirical evidence of the role of governance in sustainable tourism.

Although there are few published articles, some complex reflections can still be discussed. Studying public policy, institutional arrangements, power, values and the role of interest groups and communities in the tourism policy-making process, management of tourism destinations, among other important issues, are matters of concern when efforts to improve sustainable development of tourism are trying to be achieved. The studies on governance and sustainable tourism have been associated with some of these scopes of analysis in order to help to find solutions to catapult the metaproblem of unsustainability of tourism development in several situations. The different research analysed demonstrates that theoretical and practical findings, under the prism of governance, can give a valuable contribution to understand contemporary social, economic and political challenges and problems within the broad scope of development of sustainable tourism. There are several governance concepts, different disciplinary approaches to governance, a fuzzy scope of governance theory, and great challenges associated with specific practical areas of governance that can contribute to better understanding, planning and management of sustainable tourism. However, there is also clear evidence of the contribution that tourism itself intends to make to the theory of governance.

Some limitations can be noted in this literature review. Limited access to the full content of some articles has slightly reduced the number of items that it would, in theory, be desirable to explore in the analysis, according to tracks provided by the Scopus database. It is also recognized that outlining a generic framework on issues of governance, as presented, can lead to a limited understanding of the reality for those who do not have any previous knowledge in matters of governance, due to its level of complexity. The fact that some articles about tourism and governance do not emphasize the issue of sustainability (and as such were not analysed in this paper) does not mean they are not aware of the importance of governance to improve the development of better tourism practices; they also can contribute with important reflections to better understand and complement some issues under analysis.

Further research is needed; for instance, more analysis about the main dimensions of governance and underpinning dimensions that can be applied to sustainable tourism are needed. There is a lack of studies comparing the governance of different tourist destinations that have opted for a more sustainable development, nationally and between countries, and this requires appropriate methodologies to be defined. Destination governance is a changing mosaic of several overlapping issues and should be more closely examined, bearing in mind that tourism destinations are complex systems. The continuum of planning process, policy-making and development should be studied in the light of spatial, temporal and governance scales. An important question to ensure that good governance is implemented in a particular geographical area for intervention is to ask their stakeholders what is the best prescription (in terms of structures and process) to ensure further effectiveness and, therefore, more competitiveness and success with the resources they have at their disposal (e.g. financial, human resources, knowledge, natural and built heritage). Because the concept of governance is multidimensional, perhaps it 
should be considered that there are no standardized solutions to ensure success through a universal approach to governance in tourism destinations (also a multifaceted sector), although some fundamental considerations should be considered for common contexts. Understanding about how governance can be conceptualised and analysed to determine the effects of new arrangements and process on policy development and management of tourist destinations is very useful. Private and public sectors and other actors are being forced to promote synergies within the same geographical area of intervention in order to face global competition, and governance arrangements can facilitate this, as already described in some studies.

Governance represents a new pattern of interaction between government and society to cope with old and new problems or to create new opportunities to develop sustainable tourism. And because governance solutions can be as numerous as the units of analysis under consideration, as already advocated by several authors of different social sciences, this paper aims to contribute to those reflections more confined to the specific development of sustainable tourism. But still more similar future reflections are needed to contribute to reduce and clarify the diffuse nature of this approach. In this sense, governance contributions for the real improvement of sustainable tourism can be very challenging and not just one more philosophical utopia among others related to sustainable development.

\section{References}

Beaumont, N., Dredge, D. (2010) Local tourism governance: a comparison of three network approaches. Journal of Sustainable Tourism, 18(1), 7-28.

Bevir, M. (2007) Encyclopedia of governance. California: SAGE.

Bramwell, B. (2011) Governance, the state and sustainable tourism: A political economy approach. Journal of Sustainable Tourism, 19(4-5), 459-477.

Bramwell, B., Lane, B. (2011) Critical research on the governance of tourism and sustainability. Journal of Sustainable Tourism, 19(4-5), 411-421.
Bramwell, B., Lane, B. (2010) Sustainable tourism and the evolving roles of government planning. Journal of Sustainable Tourism, 18(1), 1-5.

Caffyn, A., Jobbins, G. (2003) Governance capacity and stakeholder interactions in the development and management of coastal tourism: Examples from Morocco and Tunisia. Journal of Sustainable Tourism, 11(2-3), 224-245

Dinica, V. (2009) Governance for sustainable tourism: a comparison of international and Dutch visions. Journal of Sustainable Tourism, 17(5), 583-603.

Dinica, V. (2006) Policy measures and governance for sustainable tourism and recreation in the Netherlands - An evaluation. Tourism, 54(3), 245-258.

Dredge, D., Whitford, M. (2011) Event tourism governance and the public sphere. Journal of Sustainable Tourism, 19(45), 479-499.

Elsevier (2012) About Scopus. Elsevier. URL: http://www.info.sciverse.com/scopus/ab out (Accessed on 05.2012).

Erkuş-Öztürk, H., Eraydin, A. (2010) Environmental governance for sustainable tourism development: Collaborative networks and organisation building in the Antalya tourism region. Tourism Management, 31(1), 113-124.

Grindle, M. S. (2007) Good enough governance revisited. Development Policy Review, 25(5), 553-574.

Hall, C. M. (2011) Policy learning and policy failure in sustainable tourism governance: from first- and secondorder to third-order change? Journal of Sustainable Tourism, 19(4-5), 649-671.

Hall, C. M. (2008) Tourism planning: policies, processes and relationships. $2^{\text {nd }} \mathrm{Ed}$. Essex: Pearson Education.

Hall, C. M. (2005) Tourism: rethinking the social science of mobility. Pearson Education.

Hall, C.M. (1999) Rethinking collaboration and partnership: A public policy perspective. Journal of Sustainable Tourism, 7(3-4), 274-289.

Higgins-Desbiolles, F. (2011) Death by a thousand cuts: Governance and environmental trade-offs in ecotourism 
development at kangaroo Island, South Australia. Journal of Sustainable Tourism, 19(4-5), 553-570.

Hunter, C. (1997) Sustainable tourism as an adaptive paradigm. Annals of Tourism Research, 24(4), 850-867.

Jamal, T., Watt, E. M. (2011) Climate change pedagogy and performative action: Toward community-based destination governance. Journal of Sustainable Tourism, 19(4-5), 571-588.

Jessop, B. (1998) The rise of governance and the risks of failure: the case of economic development. International Social Science Journal, 50(155), 2945.

Kjær, A. M. (2004) Governance. Key Concepts. Cambridge / Malden: Polity Press.

Ko, T. G. (2005) Development of a tourism sustainability assessment procedure: a conceptual approach. Tourism Management, 26, 431-445.

Lansing,P., Vries, P.D. (2007) Sustainable tourism: Ethical alternative or marketing ploy? Journal of Business Ethics, 72, 77-85.

Liu, Z. (2003) Sustainable tourism development: A critique. Journal of Sustainable Tourism, 11(6), 459-475.

Lu, J., Nepal, S. K. (2009) Sustainable tourism research: An analysis of papers published in the Journal of Sustainable Tourism. Journal of Sustainable Tourism, 17(1), 5-16.

McDonald, J. R. (2009) Complexity science: An alternative world view for understanding sustainable tourism development. Journal of Sustainable Tourism, 17(4), 455-471.

Moore, S.A., Rodger, K. (2010) Wildlife tourism as a common pool resource issue: enabling conditions for sustainability governance. Journal of Sustainable Tourism, 18(7), 831-844.

OECD (2012) OECD tourism trends and policies 2012. OECD Publishing.

Paavola, J., Gouldson, A., KluvánkováOravská, T. (2009) Interplay of actors, scales, frameworks and regimes in the governance biodiversity. Environmental Policy and Governance, 19, 148-158.
Plummer, R., Fennell, D.A. (2009) Managing protected areas for sustainable tourism: prospects for adaptive comanagement. Journal of Sustainable Tourism, 17(2), 149-168.

Rhodes, R. A. W. (1996) The new governance: Governing without government. Political Studies, XLIV(44), 652-667.

Ruhanen, L., Scott, N., Ritchie, B., Tkaczynski, A. (2010) Governance: A review and synthesis of the literature. Tourism Review, 65(4), 4-16.

Shipley, R., Kovacs, J. F. (2008) Good governance principles for the cultural heritage sector: Lessons from international experience. Corporate Governance, 8(2), 214-228

Sofield, T., Li, S. (2011) Tourism governance and sustainable national development in China: A macro-level synthesis. Journal of Sustainable Tourism, 19(45), 501-534.

Stoker, G. (1998) Governance as theory: Five prepositions. International Social Science Journal, 50(155), 17-28.

Summer, J. (2008) Governance, Globalization and Political Economy: perspectives from Canadian Adult Education. Adult Education Quarterly, 59(1), 22-41.

Trousdale, W.J. (1999) Governance in context - Boracay Island, Philippines. Annals of Tourism Research, 26(4), 840-867.

Vernon, J., Essex, S.,Pinder, D., Curry, K. (2005) Collaborative policymaking: Local sustainable projects. Annals of Tourism Research, 32(2), 325-345.

Weiss, T. G. (2000) Governance, good governance and global governance: conceptual and actual challenges. Third World Quarterly, 21(5), 795-814.

Windsor, D. (2009) Tightening corporate governance. Journal of International Management, 15, 306-16.

Zahra, A.L. (2011) Rethinking regional tourism governance: The principle of subsidiarity. Journal of Sustainable Tourism, 19(4-5), 535-552. 
Appendix A. List of articles covered in the analysis conducted (articles listed chronologically)

1. Hall, C.M. (1999) Rethinking collaboration and partnership: A public policy perspective. Journal of Sustainable Tourism,7(3-4), 274-289.

2. Trousdale, W.J. (1999) Governance in context - Boracay Island, Philippines. Annals of Tourism Research, 26(4), 840-867.

3. Caffyn, A., Jobbins, G. (2003) Governance capacity and stakeholder interactions in the development and management of coastal tourism: Examples from Morocco and Tunisia. Journal of Sustainable Tourism, 11(2-3), 224-245

4. Vernon, J., Essex, S.,Pinder, D., Curry, K. (2005) Collaborative policymaking: Local sustainable projects. Annals of Tourism Research, 32(2), 325-345.

5. Dinica, V. (2006) Policy measures and governance for sustainable tourism and recreation in the Netherlands - An evaluation. Tourism, 54(3), 245-258.

6. Lansing,P., Vries, P.D. (2007) Sustainable tourism: Ethical alternative or marketing ploy? Journal of Business Ethics, 72, 77-85.

7. Shipley, R., Kovacs, J. F. (2008) Good governance principles for the cultural heritage sector: Lessons from international experience. Corporate Governance, 8(2), 214-228

8. Dinica, V. (2009) Governance for sustainable tourism: a comparison of international and Dutch visions. Journal of Sustainable Tourism, 17(5), 583-603.

9. Plummer, R., Fennell, D.A. (2009) Managing protected areas for sustainable tourism: prospects for adaptive co-management. Journal of Sustainable Tourism, 17(2), 149-168.

10.Bramwell, B., Lane, B. (2010) Sustainable tourism and the evolving roles of government planning. Journal of Sustainable Tourism,18(1), 1-5.

11.Beaumont, N., Dredge, D. (2010) Local tourism governance: a comparison of three network approaches. Journal of Sustainable Tourism, 18(1), 7-28.

12.Moore, S.A. Rodger, K. (2010). Wildlife tourism as a common pool resource issue: enabling conditions for sustainability governance. Journal of Sustainable Tourism, 18(7), 831-844.

13.Erkuş-Öztürk, H., Eraydin, A. (2010). Environmental governance for sustainable tourism development: Collaborative networks and organisation building in the Antalya tourism region. Tourism Management, 31(1), 113-124.

14.Dredge, D., Whitford, M. (2011) Event tourism governance and the public sphere. Journal of SustainableTourism,19(4-5), 479-499.

15.Sofield, T., Li, S. (2011) Tourism governance and sustainable national development in China: A macro-level synthesis. Journal of Sustainable Tourism, 19(4-5), 501-534.

16.Zahra, A.L. (2011) Rethinking regional tourism governance: The principle of subsidiarity. Journal of Sustainable Tourism, 19(4-5), 535-552.

17. Higgins-Desbiolles, F. (2011) Death by a thousand cuts: Governance and environmental trade-offs in ecotourism development at kangaroo Island, South Australia. Journal of Sustainable Tourism, 19(4-5), 553-570.

18. Jamal, T., Watt, E. M. (2011) Climate change pedagogy and performative action: Toward community-based destination governance. Journal of Sustainable Tourism, 19(4-5), 571588

19. Hall, C.M. (2011) Policy learning and policy failure in sustainable tourism governance: From first- and second-order to third-order change? Journal of Sustainable Tourism, 19(45), 649-671. 